\title{
Study on Flood Control Planning Scheme of Main Urban Area of Qijiang District in Chongqing City
}

\author{
Changwen Li , Anqiang Li, Di Yuan, Wei Yao and Qi Li \\ Changjiang Institute of Survey, Planning, Design and Research, 430010 Wuhan, China
}

\begin{abstract}
In order to solve the flood control problems faced by the main urban area of Qijiang District in hilly areas and ensure the safety of urban flood control, based on the in-depth study of the characteristics of flood disasters and one-dimensional hydrodynamic model of the main stream of Qijiang River, the current situation and main problems of flood control in this area are analysed, and the reasons for the insufficient capacity of flood control are found out. The flood control effects of Engineering measures, such as the optimization and reconstruction of shipping cascades, river regulation, river-crossing bridges construction, levee construction and flood diversion tunnels were studied, and the flood control planning scheme was put forward. It is suggested that comprehensive governance should be carried out based on the requirements of urban landscape, and the combination scheme of cascade optimization and reconstruction + river regulation + dike construction is recommended.
\end{abstract}

\section{Basic situation of the district}

Qijiang District is located in the southwest of Chongqing City and in the middle reaches of Qijiang River. The main urban area of Qijiang District belongs to flat area, which is basically arranged along both sides of the main stream of Qijiang River; and the west bank is Gunan Street and the east bank is Wenlong Street, with the total area of $208.87 \mathrm{~km}^{2}$. The Location of the main urban area of Qijiang District is shown in Figure 1.

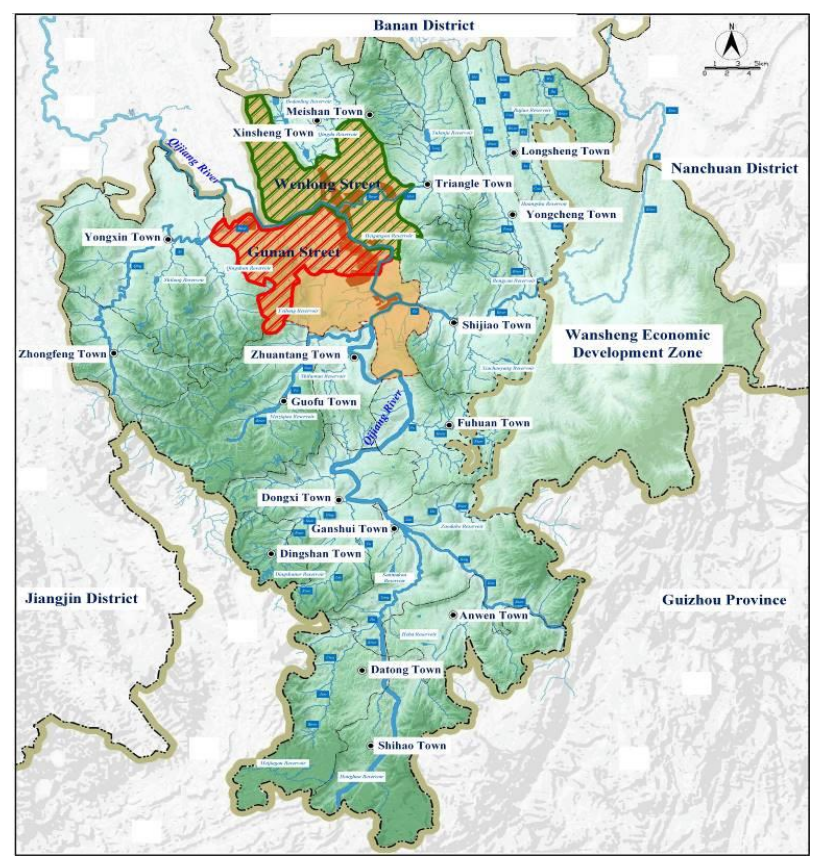

Fig. 1. Regional location of the main urban area of Qijiang District
The main stream of the Qijiang River is winding, showing an "S" type in multi-section; and the houses on both sides of the river are relatively dense, and the topography of some areas is low. It is about $5 \mathrm{~km}$ long from the upperstream Qijiang Railway Station to the downstream Urban North Bridge, and the elevation of the urban area is $221.91 \sim 260 \mathrm{~m}$. The sketch map of the main urban area of Qijiang District is shown in Figure 2. At the end of 2015, the main urban area of Qijiang District had a registered population of 191,000 and a GDP of 13.534 billion Yuan.

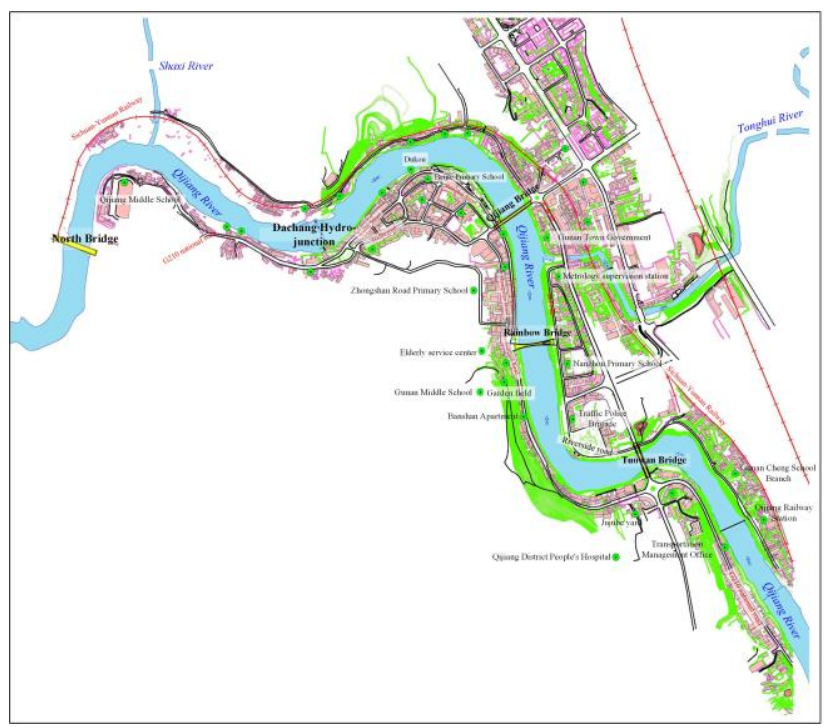

Fig. 2. The sketch map of the main urban area of Qijiang District

The Qijiang River is an important tributary on the right bank of the upper stream of the Yangtze River, 
flows from south to north through Xinchang, Songkan, Qushui, Dongxi, Qijiang urban area and Wufu, and enters the Yangtze River in Jiangjin District, with the length of $198 \mathrm{~km}$, the area of the river basin of $7140 \mathrm{~km}^{2}$, the total drop of $854.1 \mathrm{~m}$, and the average ratio of the river course of $4.31 \%$.

The Qijiang River is divided into upper, middle and lower reaches with the boundary of Qanshui Town (where Songkan River, Zaodu River and Yangdu River converge) and North Bridge in the main urban area of Qijiang District. The upstream reach is $30-60 \mathrm{~m}$ wide, 63 $\mathrm{km}$ long and $730.8 \mathrm{~m}$ drop with an average slope of the channel about $11.6 \%$, and the catchment area of 2966 $\mathrm{km}^{2}$. In the middle reaches of the river, the width of the river from Ganshui Town to Sanjiang Street, and from Sanjiang Street to North Bridge is $50-120 \mathrm{~m}$ and 100 $200 \mathrm{~m}$ respectively, distributed with deep pool and shallow area, and with gentle flow. The river length is 61 $\mathrm{km}$, and the drop is $76.8 \mathrm{~m}$ with an average slope of the river channel about $1.26 \%$, and the area of the section of $1757 \mathrm{~km}^{2}$. The lower reaches have broad water surface, small flow velocity, with the width of 80-150 m, length of $74 \mathrm{~km}$ and drop of $46.5 \mathrm{~m}$. The average slope of the channel is about $0.63 \%$, and the area of the section is $2417 \mathrm{~km}^{2}$. The Qijiang River Basin is in the shape of a heart leaf, and the river system is arranged in the shape of a tree branch. The distribution of the tributaries on both sides of the river is generally uniform, with an average width of $90 \mathrm{~km}$ in the east-west direction and an average length of $78 \mathrm{~km}$ in the north-south direction. There are 10 tributaries with a catchment area of more than $100 \mathrm{~km}^{2}$, including Yelang River, Yangdu River, Guofu River, Qingxi River and Shunxi River on the left bank, and Mugua River, Zaodu River, Fuhuan River, Pu River and Tonghui River on the right bank. The drainage map of Qijiang River Basin is shown in Figure 3.

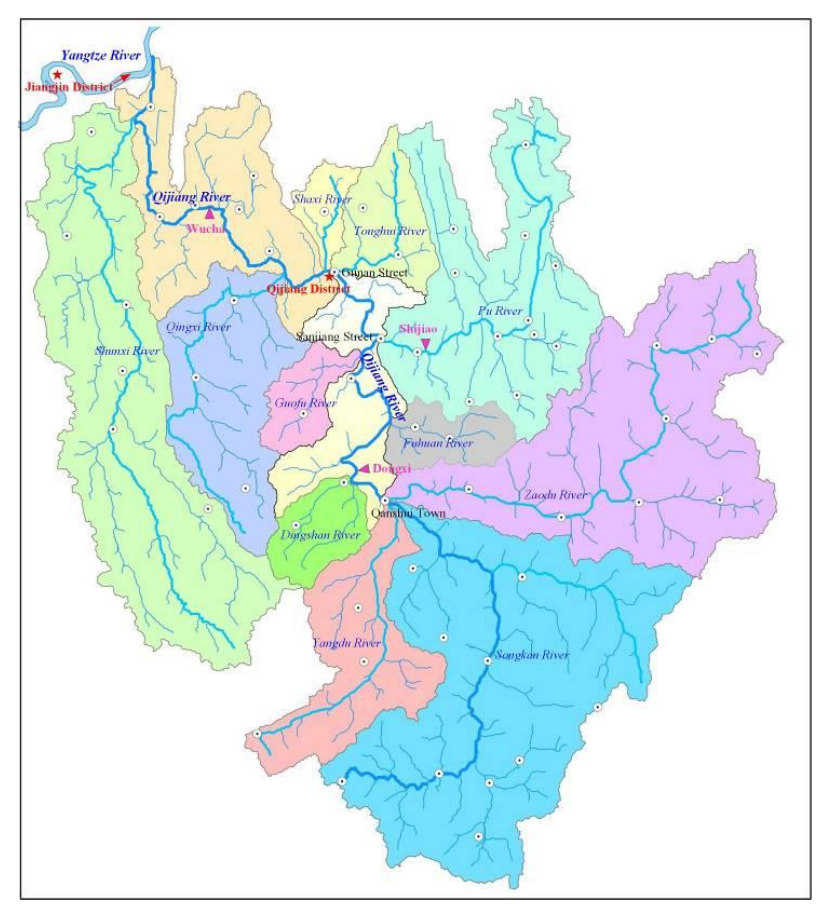

Fig. 3. Drainage map of Qijiang River basin

\section{Data and methods}

\subsection{Data sources}

There are Dongxi and Wucha hydrological stations in the main stream of Qijiang River and Shijiao Station in Puhe River, a tributary of Qijiang River. The catchment area of Dongxi Station and Shijiao Station accounted for $65.6 \%$ and $15.0 \%$ of North Bridge, $55.6 \%$ and $12.7 \%$ of Wucha Station respectively. This study collects water level and discharge data of Dongxi Station from 1970 to 2016, and Wucha Station from 1940 to 2016, and Shijiao Station from 1958 to 2016.

In this study, 67 measured river section data were used, with an average spacing of about $1107 \mathrm{~m}$ and a minimum spacing of $94 \mathrm{~m}$.

\subsection{Research methods}

This study combines the current situation and characteristics of flood control in Qijiang River and draws up several flood control planning schemes; establishes a one-dimensional hydrodynamic model of the main stream of Qijiang River to simulate the effects of various engineering control measures on the main and tributary floods and their transmission, such as rivercrossing structures (cascade hubs, bridges) and embankment protection works, river dredging regulation works, flood diversion works; calculate, analyse and compare the effect of different flood control engineering measures on flood control in the main urban area of Qijiang District and compare the proposed flood control planning schemes in many aspects, and put forward the recommended flood control planning schemes for the main urban area of Qijiang District. The research ideas are shown in Figure 4.

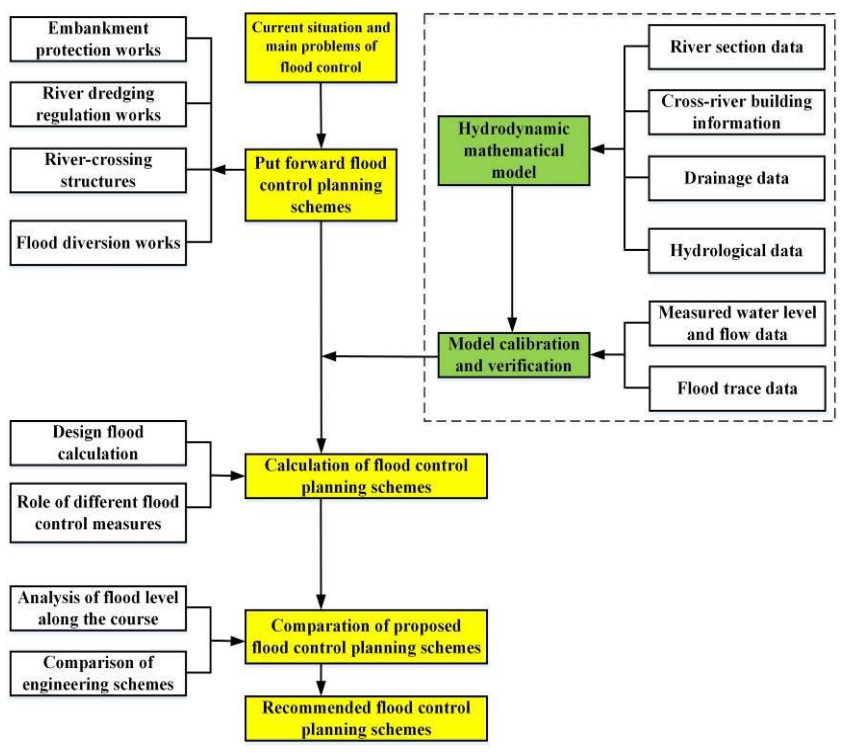

Fig. 4. Research ideas 


\subsubsection{Model construction}

Considering the distribution of hydrological station network, the location distribution of river-crossing buildings and the impact of flood control, the simulation range of one-dimensional hydrodynamic mathematical model of Qijiang main stream is set from Dongxi Hydrological Station to Wucha Hydrological Station with a total length of $84.13 \mathrm{~km}$. The research scope is shown in Figure. 5.

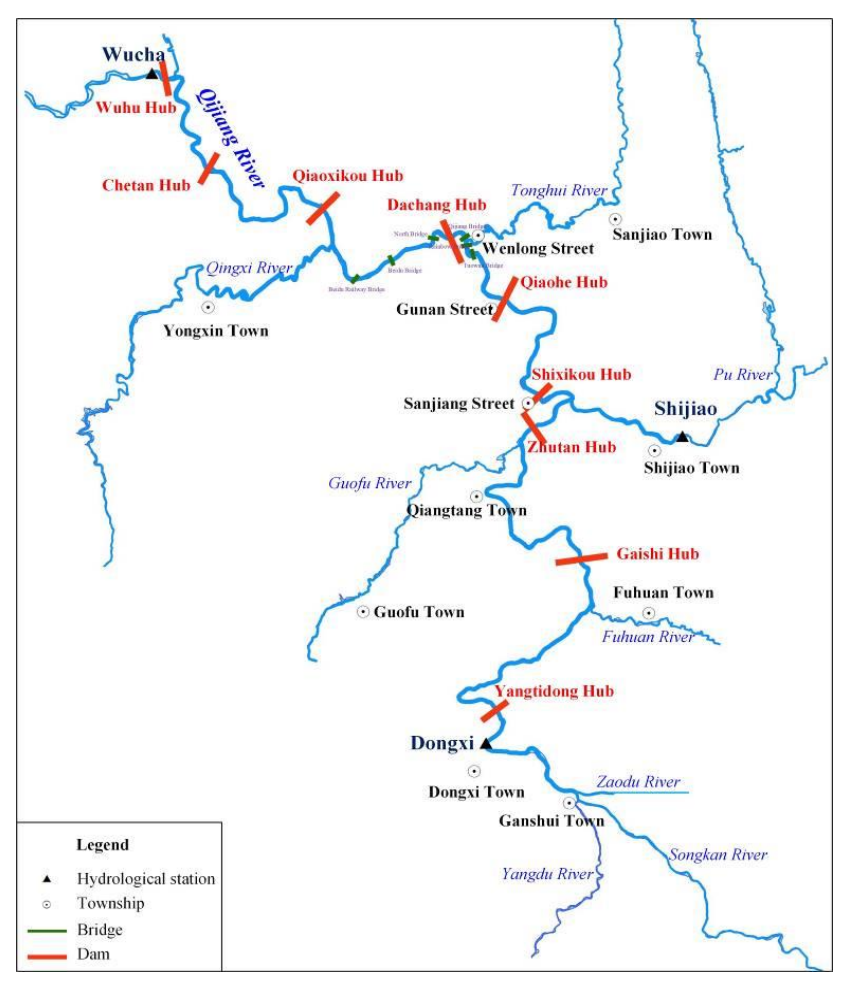

Fig. 5. Study scope of hydrodynamic model study

The upper boundary condition is the discharge process of Dongxi Hydrological Station; the lower boundary condition is the water level process or the relationship between water level and discharge of Wucha Hydrological Station; and the side inflow boundary condition is the flood process of main tributaries such as Fuhuan River, Guofu River, Pu River, Tonghui River, Qingxi River and the uncontrolled section of the main stream. There are many river-crossing structures in the main stream of Qijiang River, mainly including bridges, sluice and dam junctions, etc. According to the structure type and water-blocking condition of each bridge, the water-blocking area of the bridge is deducted from the river section in the simulation according to the waterblocking condition of the pier. The sluice and dam junction are composite structures consisting of spillway dam, spillway gate, ship lock, non-spillway dam and power station. In other words, several independent spillway weirs are added at the same location to simulate the treatment.

\subsubsection{Calibration and verification of the model}

Based on the observed data of "6.28" flood in 2016 and "8.17" flood in 1998, the established hydrodynamic models were calibrated and validated respectively. Considering the flood characteristics and flood trace data of the Qijiang River, the main river is divided into 11 sections to calculate the roughness. Figure 6 is the result of "6.28" flood process calibration in 2016; and Figure 7 is the result of "8.17" flood process verification in 1998 .

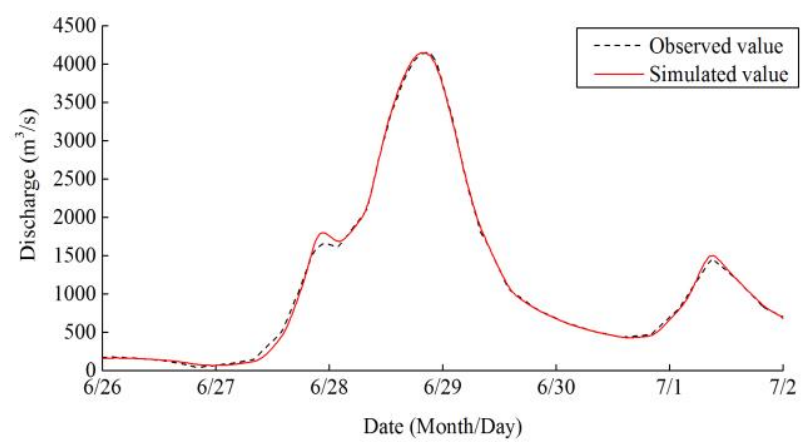

Fig. 6. Calibration results of "6.28" flood in 2016 in Wucha Station

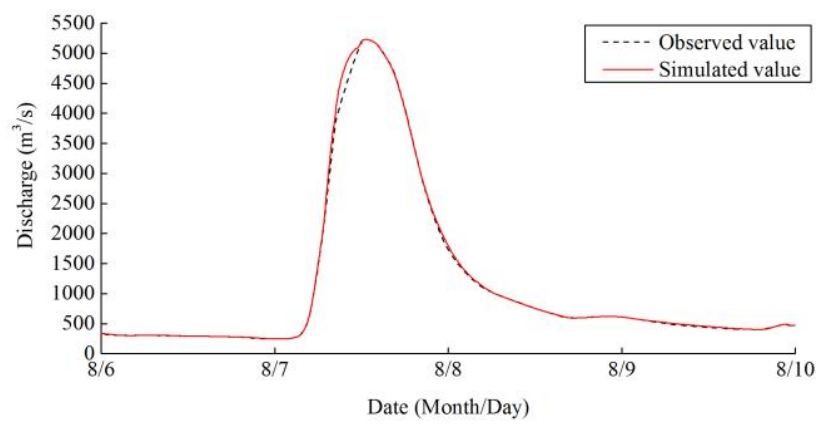

Fig. 7. Verification results of "8.17" flood in 1998 in Wucha Station

It can be seen that in the two floods, the simulated flood process at Wucha Station and the observed flood process have the same flood rising and falling trend, the peak size and peak time are in good agreement. And in the calibration and verification of the model, the peak flow errors of Wucha station are $0.02 \%$ and $0.25 \%$ respectively. The calculated results of the water surface line along the Qijiang River are basically consistent with those of the flood marks, and the average simulation error is about $0.01 \mathrm{~m}$. According to the calibration and verification results, the comprehensive roughness of 11 river sections ranges from 0.033 to 0.045 .

\section{Flood control situation analysis}

\subsection{Flood characteristics}

The Qijiang River floods are mainly caused by heavy rains, and the occurrence time of the floods corresponds to the heavy rains. The rule that the peak discharge of the lower reaches of the Qijiang River increases with the extension of the area is not obvious, which reflects that the flood of the Qijiang River mainly comes from the middle and upper reaches. The main flood season of Qijiang River is from May to September, and the maximum flood occurs from May to July, with the frequency of the maximum flood occurs from May to 
July of about $79 \%$. According to the observed data of Wucha Station from 1965 to 2016, the annual maximum flood peak appeared as early as May 2 (in 1992) and as late as October 31 (in 2008). The largest annual flood peak occurred in June and July, accounting for $57.69 \%$ of the total, followed by May, accounting for $21.15 \%$ of the total. The maximum and minimum values of the observed annual maximum flood peak series are 5220 $\mathrm{m}^{3} / \mathrm{s}$ (August 7, 1998) and $642 \mathrm{~m}^{3} / \mathrm{s}$ (June 28, 2011), the ratio of which is 8.13. According to the statistics of the measured data at Dongxi and Wucha stations, the Qijiang River flood lasted about 3 days which is not long, and the process was mostly single peak, with the maximum peak duration within one day. Qijiang River is a mountainous river, so the flood has the characteristics of fast convergence, steep rise and fall of flood process, thin peak shape and short peak duration.

\subsection{Flood disaster}

The Qijiang flood was caused by continuous heavy rains. During the 467 years from 1550 to 2016, there were 51 major floods, one in about 9 years and one catastrophic flood in every 30 years [1]. There were catastrophic floods in 1602, 1678, 1734, 1786, 1830, 1831, 1848, 1859, 1913, 1933, 1937, 1963, 1968, 1976, 1998 and 2016. Since 1913, there has been a catastrophic flood about every ten years in recent 94 years, with a higher frequency than the average. On August 7, 1998, a catastrophic flood occurred in the Qijiang River basin with daily precipitation at Dongxi Station of $158 \mathrm{~mm}$, and the peak flow of $4620 \mathrm{~m}^{3} / \mathrm{s}$ (once every $30-50$ years). The highest flood level of Rainbow Bridge in the main urban area reached $227.53 \mathrm{~m}$, exceeding the guaranteed water level of $5.03 \mathrm{~m}$, resulting in 761,000 disaster victims and 52 deaths in 22 townships in the Qijiang District, resulting in the infrastructures such as highways, railways, telecommunications, waterways and bridges has been severely damaged in the whole region $167 \mathrm{~km}^{2}$ of farmland and more than 6,000 houses have been damaged, and the direct economic loss is about 860 million Yuan.

\subsection{Current situation of flood control}

Flood control in the main urban area of Qijiang District mainly relies on dikes to prevent floods. Up till now, the total length of the embankment protection bank has been built in the flood control protection zone of the main urban area, which is $9.086 \mathrm{~km}$. (Shown in Figure. 8.)

There is no controlled flood control project in the upper reaches of the main urban area of Qijiang District, but 13 reservoirs with flood control function have been built in the tributaries of Qijiang River, including one medium-sized reservoir, twelve small (1) reservoirs and a total flood control capacity of $62631,100 \mathrm{~m}^{3}$. From the point of view of reservoir distribution, these reservoirs are located in the upper reaches of the Qijiang tributary and control the catchment area of $144.15 \mathrm{~km}^{2}$, accounting for only $3.05 \%$ of the total area of $4723 \mathrm{~km}^{2}$ under the control of North Bridge, which has little effect on flood control in the main urban area of Qijiang District.

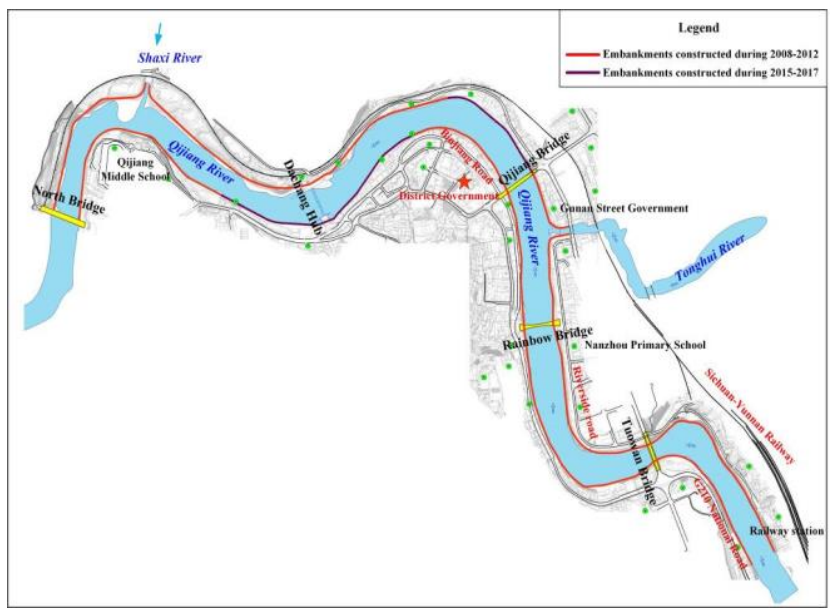

Fig. 8. Distribution map of embankment protection projects in Qijiang district of main stream of Qijiang River

\subsection{Main problems in flood control}

\subsubsection{Dike construction is not up to the planning standard and the current flood control capacity is low}

(1) Review of current flood control capacity

The main urban area of Qijiang District is basically arranged along both sides of the main stream of the Qijiang River, with dense houses on both sides and lowlying terrain. It mainly resists floods through embankment protection works. After checking, there are $9962 \mathrm{~m}$ embankments (including natural bank slopes) in the main urban area of Qijiang District. Among them, there are $3129 \mathrm{~m}$ embankments with the requirement of once-in-20-year flood control capacity, accounting for $31.4 \%$ of the total bank length, $529 \mathrm{~m}$ embankments with the requirement of once-in-5 to 10-year flood control capacity, accounting for $5.3 \%$ of the total bank length, and 6304 m embankments with less than once-infive-year flood control capacity, accounting for $63.3 \%$ of the total bank length. The implementation height and current flood control capacity of each levee section are shown in Figure. 9.

\section{(2) Analysis of fl.ood inundation effect}

The main urban area of Qijiang District has been inundated by once-in-20-years flood for about 310,000 $\mathrm{m} 2$ [2]. The largest area of inundation and the most important object of inundation are Xiabejie District on the left bank (Rainbow Bridge-Dachang Hub Section, shown in Figure. 10) and Caiba District on the right bank (Traffic Police Force-Tonghui River Estuary Section, shown in Figure. 11). Among them, the lowest ground elevation of Xiabejie area on the left bank is 225.77 $221.91 \mathrm{~m}$, which is $2.14-6.77 \mathrm{~m}$ lower than the once-in20-year water level $(227.17$ - $225.84 \mathrm{~m})$; the lowest ground elevation of Caiba area on the right bank is $223.98-222.00 \mathrm{~m}$, which is $4.06-6.13 \mathrm{~m}$ lower than the once-in-20-year water level (227.30 - $227.03 \mathrm{~m})$. Under 
the condition of once-in-20-year flood, Beijie Primary School, Qijiang District Public Security Bureau, a large number of houses, Binjiang Park and 210 National Road (about $0.84 \mathrm{~km}$ in length) in Xiabejie District on the left bank may be flooded, with an area of about $847,000 \mathrm{~m}^{2}$ flooded; Traffic Police Brigade, Forestry Bureau, Municipal Bureau, Party School of CPC Qijiang District Committee, Nanzhou Primary School, a large number of houses and Riverside Road (about $1.04 \mathrm{~km}$ in length) may be flooded, with an area of about 87.5 million $\mathrm{m}^{2}$ inundated once in 20 years.

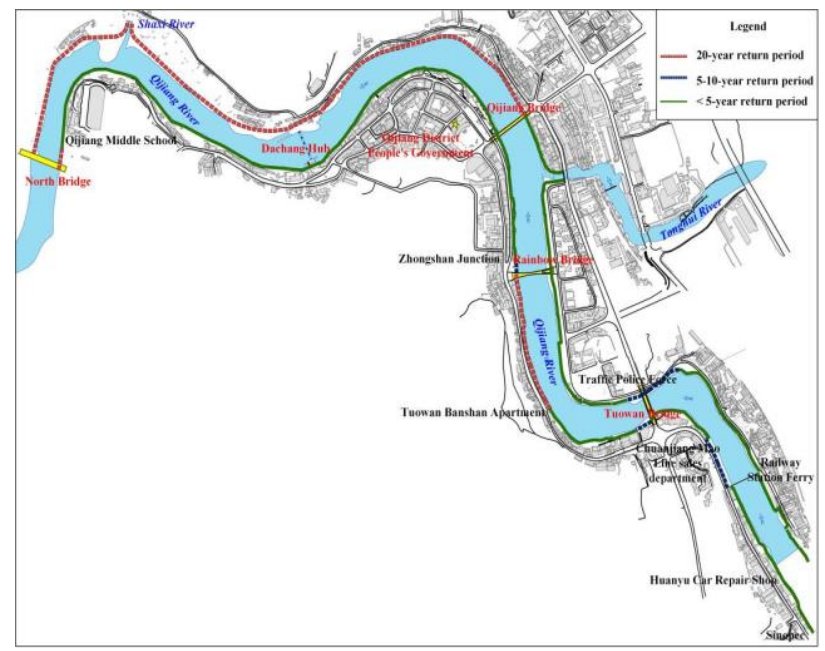

Fig. 9. Flood control capacity distribution map of dikes (including natural bank slopes) in Qijiang District

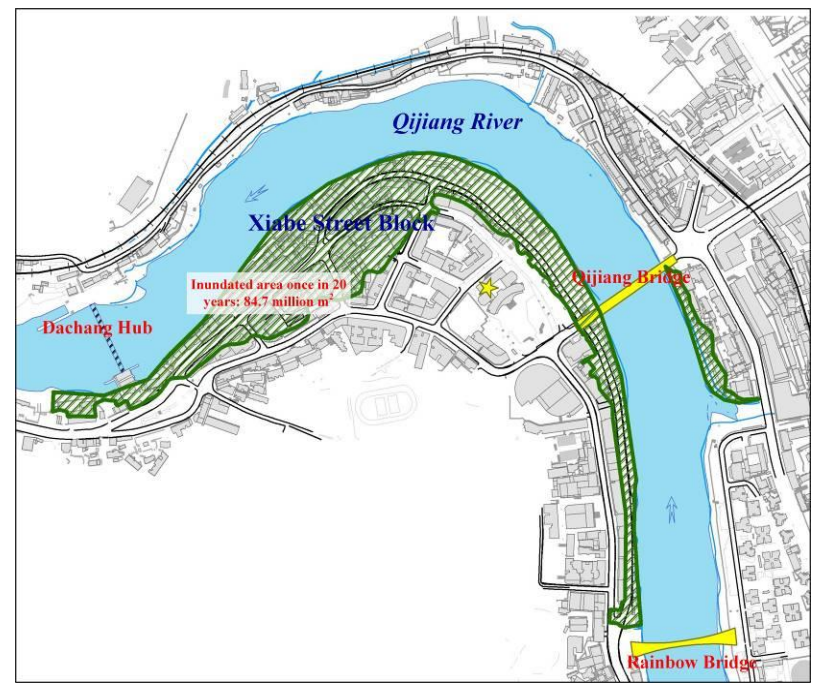

Fig. 10. Once-in-20-year flood inundation map of Xiabe Street Block on left bank

\section{(3) Calculation of Safe Discharge of River Course}

According to the lowest ground elevation of the main flood control objects in the main urban area of Qijiang District, the safe discharge of the river course is determined. The section of Rainbow Bridge is the section of flood control in the main urban area of Qijiang District [3]. The warning water level $(220.50 \mathrm{~m})$ and the guaranteed water level $(222.50 \mathrm{~m})$ of Rainbow Bridge correspond to the safe discharge of $1450 \mathrm{~m}^{3} / \mathrm{s}$ and 2340 $\mathrm{m}^{3} / \mathrm{s}$ respectively. In addition, Xiaguanwang Wharf on the left bank of the Qijiang River and the Labor Arbitration Court on the right bank of the Qijiang River are situated in a relatively low terrain and without levee protection. The corresponding safety discharge amounts are $1900 \mathrm{~m}^{3} / \mathrm{s}$ and $1400 \mathrm{~m}^{3} / \mathrm{s}$ respectively.

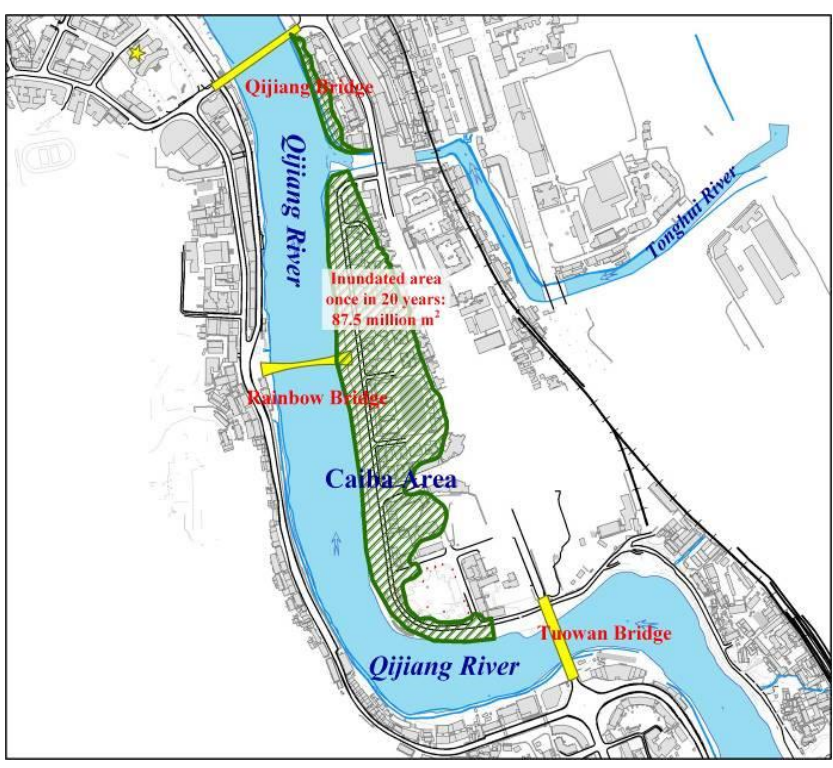

Fig. 11. Once-in-20-year flood inundation map of Caiba Area on the right bank

\subsubsection{Water-blocking of river-crossing structures and reduction of river-crossing capacity}

(1) Urban construction occupies the river course and reduces the flood discharge capacity of the river course

Due to the lack of effective management, the "disorders situations" of digging, building and collapse on both sides of the main urban section of the Qijiang River are serious, resulting in narrow and silting of some rivers, which not only raises the river bed, but also reduces the flood section and reduces the flood discharge capacity of the rivers. The flood discharge of "8.7" in 1998 was approximately the same as that of 1968 , but the water level was $1.6 \mathrm{~m}$ higher, which was directly related to the reduction of flood section and the rise of river bed.

The Qijianf River from Qijiang Railway Station (Pile No. $0+000)$ at the upper end of the main urban area of Qijiang District to the Qiaoxikou Junction Reach (Pile No. 14+289) in the lower reaches of urban area is 14.29 $\mathrm{km}$ long and the average water surface width is $147 \mathrm{~m}$ in the conditions of once-in-20-years flood. The location of the chuck is: Pile No. $5+438$ ( $895 \mathrm{~m}$ downstream of North Bridge) with a width of $110 \mathrm{~m}$; Pile No. 5+790$7+196$ (Beidu Bridge), with a width of $80-122 \mathrm{~m}$. The bayonet location of the lower reaches of the main urban area of Qijiang River is shown in Figure 12.

Rainbow Bridge, Qijiang Bridge, Beidouchang and other cross-section river bottom elevation is on the high side, resulting in high water level in the urban section of Rainbow Bridge to North Bridge and Beidouchang to Qingxi Estuary, as shown in Figure 13. 


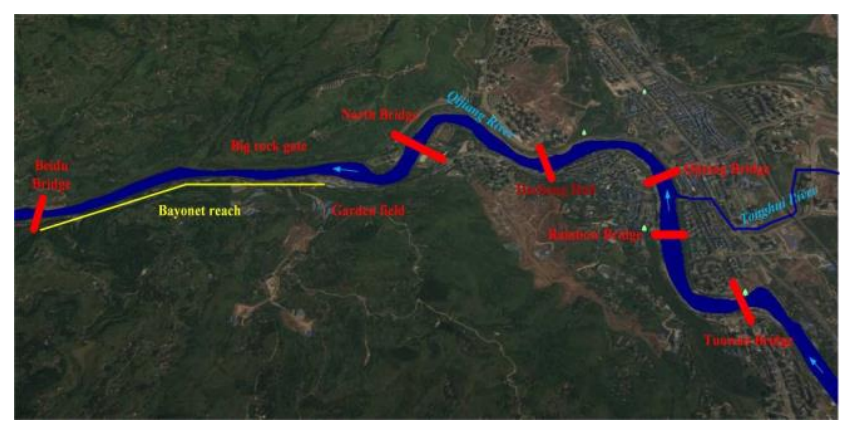

Fig. 12. Bayonet location of the lower reaches of the main urban area of Qijiang River

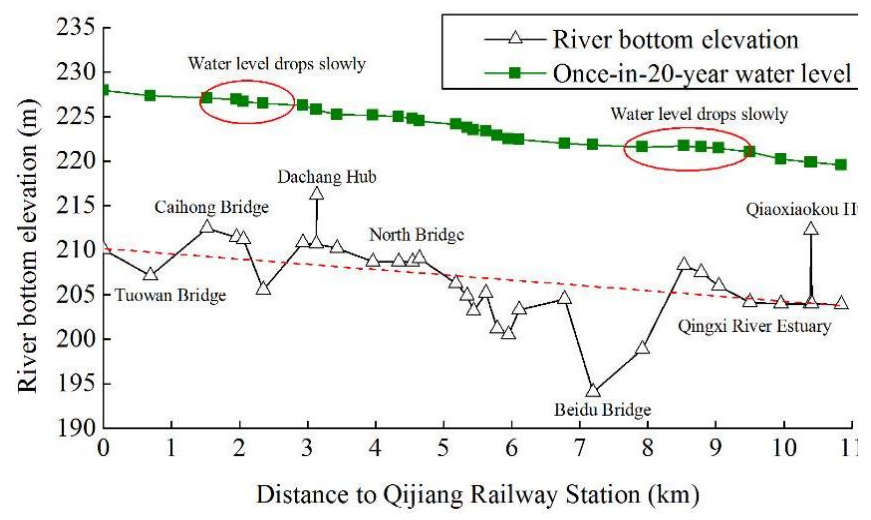

Fig. 13. River bottom elevation along the Qijiang Railway Station to Qiaoxikou Junction and the water surface line caused by once-in-20-year flood

(2) Water-blocking of river-crossing structures, resulting in reduced river-crossing capacity

Tuowan Bridge, Rainbow Bridge, Qijiang Bridge, Dachang Hub, North Bridge and other river-crossing structures have been built in the main urban area of Qijiang River. Beidu Bridge, Qiaoxikou Hub, Chetan Hub and other river-crossing structures have been built in the lower reaches of the urban area. To a certain extent, these buildings affect the flood carrying capacity of the Qijiang River, raise the flood level of the Qijiang River and increase the flood control pressure.

There are six sluices and dams, Wufu, Chetan, Qiaoxikou, Dachang, Qiaohe and Shixikou, with obvious water-blocking in Qijiang main stream with waterblocking rates of $55 \%, 40 \%, 49 \%, 27 \%, 32 \%$ and $29 \%$ respectively in the case of the control design water level for the requirement of once-in-20-year flood. The Qijiang Bridge and North Bridge are the most obvious bridges for flood control in the urban section of the Qijiang River, and the water resistance rates are $20 \%$ and $8 \%$ respectively when the design level of flood control which meets the requirement of once-in-20-years flood.

\subsection{Flood control situation analysis}

The Qijiang River is a mountainous river. The flood is mainly caused by heavy rain. The catchment area of North Bridge in the main urban area of Qijiang District is $4723 \mathrm{~km}^{2}$. Most of the tributaries in the upper reaches of the urban area are located in the center of the rainstorm and the stream gradients of the rivers are larger. The time for the flood to spread to the main urban area of Qijiang District is shorter. According to observation, it takes only 4 - 5 hours the flood peak to reach the main urban area of Qijiang District through Dongxi Hydrological Station, it takes only 3 - 4 hours for the peak to reach the main urban area of Qijiang District through Shijiao Hydrological Station, but there are more bends in the middle and lower reaches of the main river, the stream gradient is relatively flat, and the flood discharge is not smooth. In addition, nine navigation cascades and many bridges built in the middle and lower reaches of the river block the flood, which results in the "small flood peak and high water level" in the main urban area of Qijiang District, frequent floods, and even caused the interruption of Chongqing-Guizhou Railway. The situation of flood control is not optimistic.

After decades of construction of flood control projects, the main urban area of Qijiang District has basically formed a comprehensive flood control system based on embankment protection bank, river regulation and non-engineering measures, and its flood control capacity has been improved. However, due to many reasons, there are some factors such as unqualified levee construction, narrow river channel, serious water blocking of some cross-river buildings, etc. The current flood control capacity is less than the requirement of once-in five -years flood, at present, the discharge capacity of the main urban reach of Qijiang District is about $2340 \mathrm{~m}^{3} / \mathrm{s}$. If there is a once-in-20-year flood in 20 years, it will cause inundation loss about 189,000 people, $700,000 \mathrm{~m}^{2}$ housing area, $5 \mathrm{~km}$ transportation trunk line, 7 administrative departments, 2 schools and 626 houses in the main urban area of Qijiang District, without considering the condition of breaking dikes, as shown in Figure. 14.

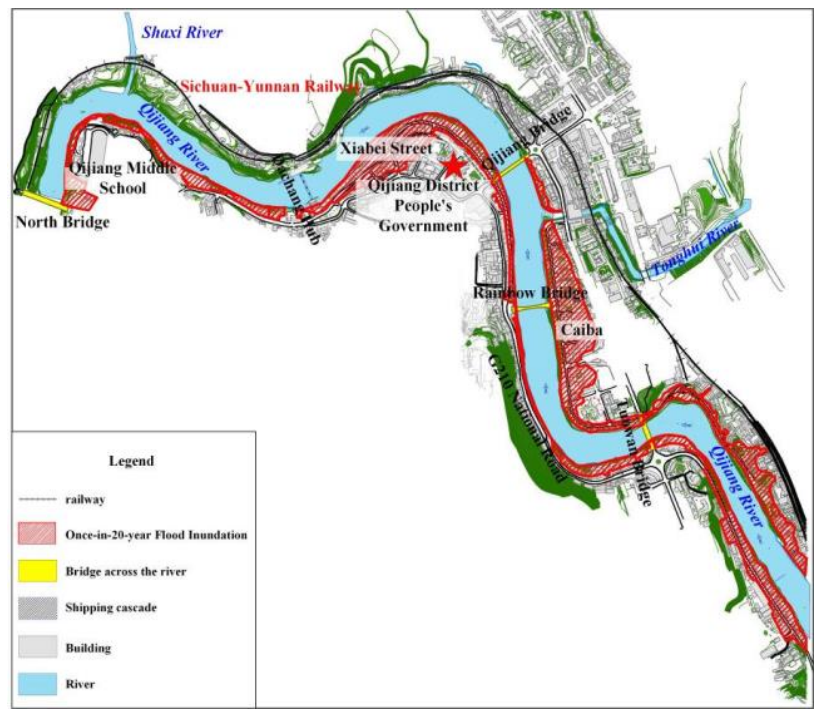

Fig. 14. Once-in-20-year flood inundation map of Qijiang District

With the rapid development of economy, society and urbanization in the main urban area of Qijiang District, the population and wealth are more concentrated. Once a flood occurs, the loss will be more serious, and the situation of flood control is still grim. 


\section{Study on flood control planning scheme}

\subsection{Planning principles}

Adhere to the principle of people-oriented. Construct a perfect flood control system, comprehensively improve the city's flood control capacity, and ensure the safety of people's lives and property.

Adhere to the principle of overall planning and consideration. The flood control objectives, standards and layout of flood control projects formulated in flood control planning should be coordinated with the comprehensive river basin planning and the overall urban and rural planning of Qijiang District.

Adhere to the principle of harmonious coexistence between man and nature. Urban flood control projects should be combined with improving the ecological environment, fully protect the existing natural ecological environment, and make it play its role in flood control.

Adhere to the principle of combining engineering with non-engineering measures, which emphasizes the combination of engineering measures and nonengineering measures, taking various measures for comprehensive control, highlighting the overall role of flood control system.

Adhere to the principle of comprehensive utilization. The combination of flood control engineering and urban water environment improvement, urban beautification and greening, and municipal traffic construction makes flood control engineering a new landscape of modern cities.

\subsection{Planning objectives}

Consolidate and improve the existing flood control system to ensure the safety of people's lives and property in the main urban area of Qijiang District. Through flood control engineering measures such as levees and river regulation, the main urban area of Qijiang District has reached the standard of once-in-20-years flood control [4-6].

\subsection{Drafting of flood control planning scheme}

Considering the needs of urban development, on the basis of properly heightening and reinforcing embankments, combined with river regulation and reconstruction of river-crossing buildings, new flood diversion tunnels will be built when necessary, so that the flood control standard of Qijiang urban area will meet the requirement of once-in-20-years flood. For this reason, this paper puts forward four single project schemes and combination schemes for levee heightening and strengthening, river course regulation, river-crossing building modification, new flood diversion tunnel.

\subsubsection{Dike heightening and reinforcement scheme}

The current safety discharge of the main urban area of Qijiang District is only $2340 \mathrm{~m}^{3} / \mathrm{s}$, less than the requirement of once-in-5-years flood. Therefore, strengthening measures can be taken to improve the river capacity. However, due to the development of the city, there are dense houses near the embankments on both sides of the Qijiang River. If the original embankment line is built according to the flood control standard of once-in-20-years flood, the maximum height of the embankment body will reach $10.82 \mathrm{~m}$, and the maximum height of the top of the embankment will appear $7.75 \mathrm{~m}$ above the ground. The main urban area of Qijiang District is a typical mountain city, and the urban land is tense. The flood of Qijiang River across the city rises and falls sharply. A flood peak lasts for a short time, about one day. On the one hand, the construction of excessively high embankments destroys the style and features of the mountain city and seriously affects the urban landscape. On the other hand, it will occupy precious urban land, resulting in the demolition of a large number of houses on the bank along the river. According to the topographic characteristics of Qijiang urban area, embankments should be properly heightened and strengthened according to the needs of urban construction.

\subsubsection{River regulation scheme}

\section{(1) Bayonet expansion scheme}

The bayonet reach of Qijiang urban area is from the sewage treatment plant downstream of North Bridge to Beidu Bridge. Considering that the right bank of the bayonet reach is along the Chongqing-Guizhou Railway and the left bank is along the G210 National Road and dense residential areas, in order to maintain the stability of the bank slope, the width of the river channel should not be too large and the excavation slope should not be too steep. According to the river topography, the current slope ratio between sewage treatment plant and Beidu Bridge is $1: 1.89-1: 2.28$, and the slope is steep, so it is not suitable to widen the river.

(2) River dredging scheme

Rainbow Bridge to North Bridge and Beidouchang to Qingxi River Estuary reaches have high river bottom elevation, which makes the river water level in the urban area high, resulting in poor flood discharge, so dredging regulation can be considered. It is planned to dredge 0.44 $\mathrm{km}$ from Rainbow Bridge to Qijiang Bridge and $1.61 \mathrm{~km}$ from Dachang Junction to North Bridge in the main urban area of Qijiang District, and Beiduchang reach at the lower reaches of the main urban area with a total of $5.79 \mathrm{~km}$. The dredging depth is $0.20-4.33 \mathrm{~m}$ and the dredging volume is about $910,000 \mathrm{~m}^{3}$.

\subsubsection{Renovation scheme of river-crossing buildings}

There are a large number of river-crossing bridges and navigation and power junctions crowding flood section in the urban area and downstream section of Qijiang 
River main stream, which results in poor discharge capacity and affects flood control capacity. Consideration should be given to the reconstruction of river-crossing structures with serious water-blocking to ensure adequate flood-discharge sections.

\section{(1) Cascade Optimization Renovation Scheme}

The cascades of Dachang, Chetan and Shixikou, which affect the flood discharge capacity of the river course in the main urban area of Qijiang River, are planned to dismantled. The cascade planning schemes of Wufu, Qiaoxikou, Qiaohe, Zhutan and Yangtidong are optimized [7]. All cascade hubs are revamped with the whole sluice scheme [8]. The sluice gates are opened during flood season to increase the flood discharge capacity and reduce the water blocking effect. After the optimization and transformation of the shipping cascades in the Qijiang main stream, the height of the weir top of each cascade spillway sluice has decreased, with a drop value of $2.3-6.2 \mathrm{~m}$, and the net overflow width of Chetan, Dachang and Shixikou has greatly increased after the dismantlement of the three hubs.

\section{(2) Bridge Renovation Scheme}

There are four river-crossing bridges in the main urban area of Qijiang District of the main stream of Qijiang River. And the bridges with obvious flood control resistance effect include Qijiang Bridge and North Bridge, which were built in 1972 and 2009 respectively. The proportion of water-blocking area under the condition of once-in-20-year flood is $20 \%$ and $8 \%$ respectively. The two bridges can be demolished, reconstructed or reconstructed to reduce their adverse effects on flood control [7].

\subsubsection{Tunnel flood diversion scheme}

The contradiction between insufficient discharge capacity of river course in Qijiang urban area and large peak flood of Qijiang River is very prominent. Only levee heightening and reinforcing, river course regulation and river-crossing bridge reconstruction have a very limited role in improving flood control capacity of main urban area of Qijiang District. According to the analysis, the whole length of reach from the Qiaohe dam site to Beidudchang of Qijiang main stream is $11.6 \mathrm{~km}$. Under the current situation, the river course is of "S" type, with large curvature and obvious water-blocking effect. It can be considered to construct a diversion channel of about $6.12 \mathrm{~km}$ between "single stone" and the upstream of Beidouchang to speed up the flood discharge and increase the discharge capacity of main urban reach. The entrance of Qijiang flood diversion tunnel is near Gunan Street, about $3.5 \mathrm{~km}$ upstream of Qijiang city, and the exit is near Beidou, about $5 \mathrm{~km}$ downstream of Qijiang city. The tunnel location is shown in Figure 15.

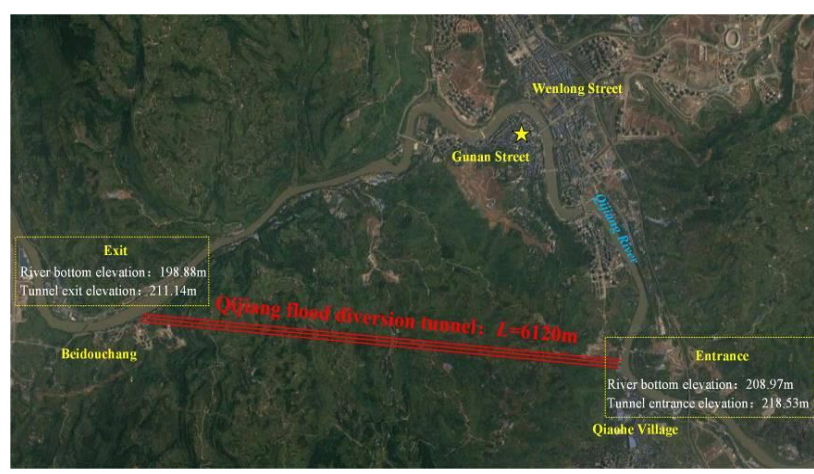

Fig. 15. Diagram of the location of the diversion tunnel

\subsubsection{Planning scheme for combined flood control projects}

The engineering measures of shipping cascade optimization reconstruction, river course regulation, river-crossing bridge reconstruction, dike construction, flood diversion tunnel and the combination scheme of these measures were compared and studied. Through technical and economic comparison, it puts forward the recommendation scheme that the flood control standards of the main urban area of Qijiang District reach the requirement of once-in-20-years flood.

The study of flood control planning is carried out at two levels: the basic plan and the standard plan. The basic scheme is easy to implement under the current conditions and has little influence on the project. The standard scheme is a comparative analysis of the project schemes that meet the planning flood control standard on the premise of implementing the basic scheme.

Among the planning schemes of cascade optimization reconstruction, river-crossing bridge reconstruction, dike construction and flood diversion tunnel, the cascade optimization reconstruction scheme has been approved at present, and this plan takes it as the basic scheme to research; the investment scale of river regulation and river-crossing bridge reconstruction is relatively small compared with that of dike construction and tunnel construction, so it is planned to be included in basic programme research. The levee construction scheme involves the difference between the levee top elevation and the ground elevation along the bank, which causes the problems of land expropriation, demolition and urban landscape, and the investment scale of the tunnel flood diversion scheme is large, so this plan compares the two schemes into the standard plan.

\section{(1) Basic scheme}

Ascade optimization reconstruction + River regulation, or cascade optimization reconstruction + river regulation + bridge reconstruction. The implementation of the basic scheme can improve the discharge capacity of the main urban reach in the main stream of the Qijiang River, but it still fails to meet the flood control standard of once-in20-years flood.

\section{(2) Standard Scheme}

On the basis of the basic scheme, measures such as heightening and reinforcing dikes and building new 
flood diversion tunnels have been taken to make the main urban area of Qijiang District reach the flood control standard of once-in-20-years-flood.

\subsection{Basic scheme research}

\subsubsection{Effectiveness of scheme implementation}

Through mathematical model calculation, under the condition of design flood once-in-20-years, the implementation effect of cascade optimization reconstruction, river regulation and bridge reconstruction schemes is shown in Figure 16 and Table 1. It can be seen that:

(1) Implementing Effect of Cascade Optimization Reconstruction Scheme

After once-in-20-years design flood, the water level at the Dachang junction will be reduced by $0.04 \mathrm{~m}$ after the implementation of the cascade optimization reconstruction scheme. The water level in the upper reaches of the Dachang junction decreases greatly, reaching $0.22-0.38 \mathrm{~m}$; and the water level in the downstream reaches of the Dachang junction decreases slightly, ranging from 0.09 to $0.12 \mathrm{~m}$. The discharge capacity of the Tonghui River estuary in the main urban area of Qijiang River District will be increased from $2340 \mathrm{~m}^{3} / \mathrm{s}$ to $2600 \mathrm{~m}^{3} / \mathrm{s}$, and the discharge capacity will be increased by $260 \mathrm{~m}^{3} / \mathrm{s}$. The flood control effect is obvious.

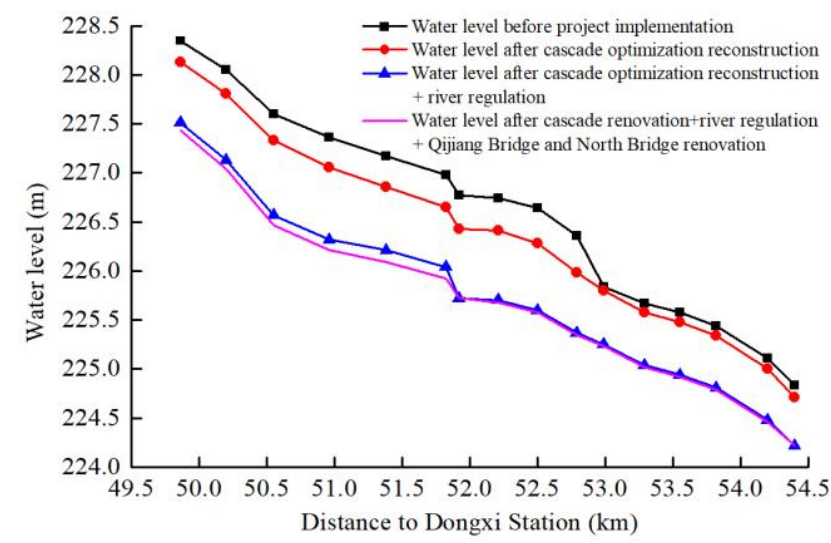

Fig. 16. Water levels of different basic schemes under the condition of once-in-20-years flood

Table 1. Discharge capacity of different basic schemes under the condition of once-in-20-years flood.

\begin{tabular}{|c|c|c|c|c|}
\hline & $\begin{array}{c}\text { Before } \\
\text { project } \\
\text { implem } \\
\text { entatio } \\
\mathrm{n}\end{array}$ & $\begin{array}{c}\text { Cascad } \\
\mathrm{e} \\
\text { optimiz } \\
\text { ation } \\
\text { reconst } \\
\text { ruction }\end{array}$ & $\begin{array}{c}\text { Cascade } \\
\text { optimizatio } \\
\mathrm{n} \\
\text { reconstructi } \\
\text { on + river } \\
\text { regulation }\end{array}$ & $\begin{array}{c}\text { Cascade } \\
\text { renovation + river } \\
\text { regulation + } \\
\text { Qijiang Bridge } \\
\text { and North Bridge } \\
\text { renovation }\end{array}$ \\
\hline $\begin{array}{c}\text { Discharge } \\
\text { Capacity } \\
\left(\mathrm{m}^{3} / \mathrm{s}\right)\end{array}$ & 2340 & 2600 & 2960 & 3020 \\
\hline
\end{tabular}

(2) Implementation Effect of Cascade Optimization Reconstruction +River Regulation Scheme
On the basis of the cascade optimization renovation scheme, river dredging regulation is further implemented. Under the condition of once-in-20-years flood, the water level in the urban area of Qijiang River can be further reduced by $0.49-0.76 \mathrm{~m}$ compared with the cascade optimization renovation scheme. The discharge capacity of Tonghui River estuary will be increased from 2600 $\mathrm{m}^{3} / \mathrm{s}$ of the cascade optimization renovation scheme to $2960 \mathrm{~m}^{3} / \mathrm{s}$, and the discharge capacity will be increased by $360 \mathrm{~m}^{3} / \mathrm{s}$. The flood control effect is obvious.

(3) Implementation Effect of Cascade Optimization Reconstruction + River Regulation + Bridge Reconstruction Scheme

On the basis of cascade optimization and river regulation, the Qijiang River Bridge and North Bridge are demolished and rebuilt, and the river channel dredging at the bridge site is coordinated. After the implementation of the scheme, the flood levels of the urban section above the Qijiang Bridge and the section from the Qijiang Bridge to North Bridge are reduced by 0.08 $0.12 \mathrm{~m}$ and $0.00-0.02 \mathrm{~m}$, respectively, compared with the cascade optimization and river regulation scheme. The discharge capacity of Tonghui River Estuary in the main urban area of Qijiang District will be increased from $2960 \mathrm{~m}^{3} / \mathrm{s}$ to $3020 \mathrm{~m}^{3} / \mathrm{s}$ after the implementation of the cascade optimization reconstruction + river regulation scheme, and the discharge capacity will be increased by $60 \mathrm{~m}^{3} / \mathrm{s}$. Therefore, the flood control effect of bridge reconstruction is not significant, and that of Qijiang bridge reconstruction is better than that of North bridge reconstruction.

\subsubsection{Selection of basic schemes}

In summary, the flood control effect of cascade optimization reconstruction and river regulation is prominent, which improves the discharge capacity of urban reaches by $260 \mathrm{~m} 3 / \mathrm{s}$ and $360 \mathrm{~m}^{3} / \mathrm{s}$ respectively, and the cost of river regulation by calculation is 0.19 billion yuan. The flood control effect of Qijiang Bridge reconstruction is smaller than that of cascade optimization reconstruction and river regulation, which improves the discharge capacity of urban reaches by 60 $\mathrm{m}^{3} / \mathrm{s}$. The cost of bridges demolition and reconstruction (including the construction of temporary traffic bridges) is 555 million yuan, and the investment scale is much larger than that of river dredging. The Qijiang Bridge is an important part of the traffic network in the Qijiang urban area. The bridge affects land transportation and water navigation in the process of demolition and reconstruction. The effect of flood control in the reconstruction of North Bridge is the least obvious, only reducing the flood level at bridge site by $0.02 \mathrm{~m}$ under the requirement of once-in-20-years flood, but the investment will be increased by 0.68 billion Yuan. Therefore, this plan will take cascade optimization reconstruction + river regulation as the basic scheme. At this stage, bridge reconstruction is not considered. When the conditions are enough, the Qijiang Bridge can be demolished and reconstructed. 


\subsubsection{Recommendation of basic schemes}

This plan recommends cascade optimization and river regulation as the basic scheme. After the implementation of the scheme, the discharge capacity of the main urban area of Qijiang District has been increased from 2340 $\mathrm{m}^{3} / \mathrm{s}$ to $2960 \mathrm{~m}^{3} / \mathrm{s}$; the length of the reach whose embankment standard reaches the requirement of oncein-20-years flood has been increased from $3510 \mathrm{~m}$ to $3579 \mathrm{~m}$, with an increase of $69 \mathrm{~m}$; and the length of the reach whose flood control capacity has met the requirement of once- in-10-20 years flood has been increased from $305 \mathrm{~m}$ to $1163 \mathrm{~m}$, with an increase of 858 $\mathrm{m}$. The length of the reach of once-in- 5 to 10 years flood increased from $102 \mathrm{~m}$ to $1419 \mathrm{~m}$, increasing by $399 \mathrm{~m}$; the length of the reach with control capacity of less than the requirement of once-in-5-years flood decreased from $5127 \mathrm{~m}$ to $3801 \mathrm{~m}$, decreasing by $1326 \mathrm{~m}$. The change of flood control situation is shown in the Figure. 17.

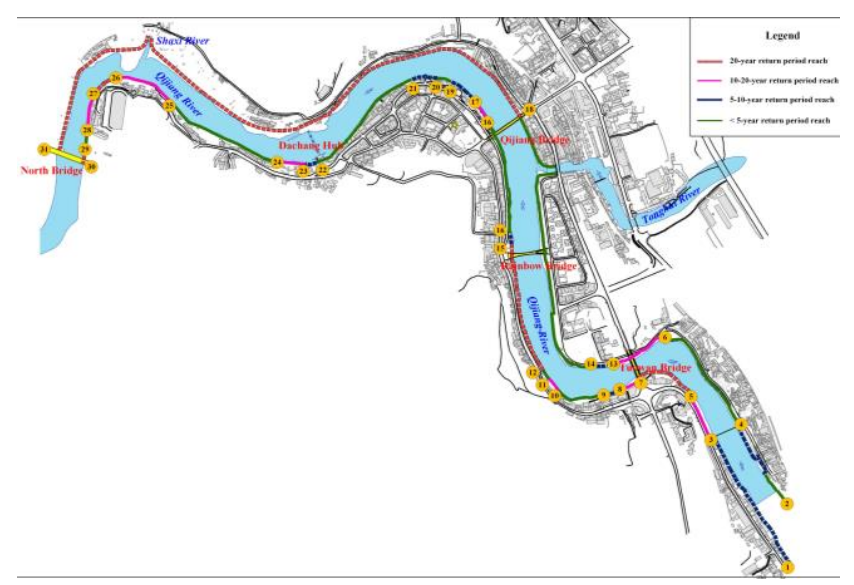

Fig. 17. Subsection diagram of flood control capacity in the main urban area of Qijiang District after the implementation of basic scheme

\subsubsection{Research on standard scheme}

On the basis of the basic scheme (cascade optimization reconstruction + river regulation), measures such as heightening and reinforcing dikes and new flood diversion tunnels are taken to raise the flood control standard of the main urban area of Qijiang District to the requirement of once-in-20-years flood.

Based on the current flood control capacity of each levee section, four combined schemes are proposed as follows:

Combination scheme 1: cascade optimization reconstruction + river regulation + once-in-20-year flood requirement dike construction. As for dike construction scheme, the dike line of Qijiang County Flood Control Planning Report (2007) is basically arranged along the waterfront of Dachang and Qiaoxikou hydro-junctions after impoundment. It is necessary to build and heighten the bank protection of $5507 \mathrm{~m}$ ( $876 \mathrm{~m}$ of which is newly built); the slope protection height is $1.29-10.79 \mathrm{~m}$, the average height is $5.48 \mathrm{~m}$, and the house demolition area is about $451,800 \mathrm{~m}^{2}$, so the removal resistance is huge and difficult to implement in the near future. Considering the flood control effect, urban landscape, urban transportation, land requisition and demolition, project investment and other factors, this plan has partially optimized the embankment line and embankment type of Qijiang County Flood Control Planning Report (2007). Five types of embankment are adopted, including flood wall, wave wall, assembled flood wall, embankment-road combination, land requisition and demolition. The total length of the levee is $4978 \mathrm{~m}$; the height of the levee is reduced by $529 \mathrm{~m}$; the height of the levee is $0.50-5.48 \mathrm{~m}$; the area of house demolition is $103,600 \mathrm{~m}^{2}$; the investment of the project is reduced by $348,200,000 \mathrm{~m}^{2}$; the width of flood discharge is increased by $5-60 \mathrm{~m}$; the maximum flood level can be reduced by $0.01-100 \mathrm{~m}$, and the area of demolition is constructed according to the riverbank park. It satisfies the requirement of two-way view both inside and outside and hydrophilicity embankment for citizens and tourists, greatly improves the urban appearance, and conforms to the strategic orientation of the leisure tourism resort and modern landscape pastoral city in the main urban area of Qijiang District.

Combination scheme 2: cascade optimization reconstruction + river regulation + once-in- 10-years flood requirement dike construction + tunnel flood diversion. A new once-in-10-years flood dike with the length of $4314 \mathrm{~m}$, a height of $0.06-3.79 \mathrm{~m}$ and a demolition area of 10 million $\mathrm{m}^{2}$ is built. A $6.12 \mathrm{~km}$ long flood diversion tunnel is built between Dushitou and the upstream of Beidou. The designed flood diversion flow is $800 \mathrm{~m}^{3} / \mathrm{s}$ and the total investment is about 2.945 billion yuan.

Combination scheme 3: cascade optimization reconstruction + river regulation + once-in- five-years flood requirement dike construction + tunnel flood diversion. The newly built embankment for the requirement of once-in- five-years flood is $2191 \mathrm{~m}$; the height of the embankment is $0.02-2.20 \mathrm{~m}$; and the area of house demolition is 27.5 million $\mathrm{m}^{2}$. Three parallel unconfined gate-type tunnels are adopted. The designed diversion flow of the diversion tunnel is $1630 \mathrm{~m}^{3} / \mathrm{s}$, with a total investment of about 4368 million yuan.

Combination scheme 4: cascade optimization reconstruction + river regulation + tunnel flood diversion. The scale of flood diversion tunnel is as follows: the designed flood diversion flow is $1940 \mathrm{~m}^{3} / \mathrm{s}$, and three parallel unconfined gate-type tunnels are adopted. The length of a single tunnel is about $6.12 \mathrm{~km}$, and the net section size is $13 \mathrm{~m} \times 16.38 \mathrm{~m}$ (width $\times$ height). The total investment is about 5.327 billion Yuan.

The results of the four combinations are shown in Table 2 .

(1) Flood control effect after the implementation of the project

All the four combination schemes can raise the flood control standard of Qijiang District's main urban area to the standard of once-in-20-years flood, and the flood control effect of each project scheme is the same.

\section{(2) Technical difficulty}

The scale of flood diversion project of combination scheme 3 (cascade optimization reconstruction + river 
Table 2. Selection of once-in-twenty-years flood control planning schemes.

\begin{tabular}{|c|c|c|c|c|c|c|c|c|c|c|c|}
\hline \multirow{2}{*}{\multicolumn{2}{|c|}{ Schemes }} & \multirow[b]{2}{*}{ Engineering scheme } & \multirow[b]{2}{*}{$\begin{array}{c}\text { River } \\
\text { regulati } \\
\text { on }(100 \\
\text { million } \\
\text { Yuan) }\end{array}$} & \multicolumn{3}{|c|}{$\begin{array}{l}\text { Land expropriation } \\
\text { and demolition (100 } \\
\text { million) }\end{array}$} & \multirow[b]{2}{*}{$\begin{array}{c}\text { Emb } \\
\text { ankm } \\
\text { ent } \\
\text { const } \\
\text { ructi } \\
\text { on } \\
(100 \\
\text { milli } \\
\text { on })\end{array}$} & \multirow[b]{2}{*}{$\begin{array}{c}\text { Flood } \\
\text { divers } \\
\text { ion } \\
\text { Tunne } \\
\text { ls } \\
(100 \\
\text { millio } \\
\text { n) }\end{array}$} & \multirow[b]{2}{*}{$\begin{array}{l}\text { Tota } \\
1 \\
\text { econ } \\
\text { omic } \\
\text { costs } \\
(100 \\
\text { milli } \\
\text { on })\end{array}$} & \multirow[b]{2}{*}{$\begin{array}{c}\text { Advantag } \\
\text { es }\end{array}$} & \multirow[b]{2}{*}{$\begin{array}{l}\text { Disadvant } \\
\text { ages }\end{array}$} \\
\hline & & & & $\begin{array}{c}\text { Remo } \\
\text { val } \\
\text { costs } \\
\text { involv } \\
\text { ed in } \\
\text { Levee } \\
\text { Const } \\
\text { ructio } \\
n\end{array}$ & \begin{tabular}{|l|} 
demoli \\
tion \\
costs \\
involv \\
ed in \\
Flood \\
diversi \\
on \\
Tunnel \\
s \\
\end{tabular} & Total & & & & & \\
\hline $\begin{array}{l}\text { Co } \\
\text { mbi } \\
\text { nati } \\
\text { on } \\
\text { sch } \\
\text { em } \\
\text { el }\end{array}$ & $\begin{array}{l}\text { cascade } \\
\text { optimization } \\
\text { reconstruction } \\
+\quad \text { river } \\
\text { regulation }+ \\
\text { once-in-20- } \\
\text { year dike } \\
\text { construction }\end{array}$ & $\begin{array}{l}\text { The river channel regulation is } \\
5.79 \mathrm{~km} \text {; the building of } \\
\text { embankment involves the } \\
\text { demolition area of } 1036,000 \\
\mathrm{~m}^{2} \text {; the newly built } \\
\text { embankment is } 4978 \mathrm{~m} \text {, and } \\
\text { the height of the embankment } \\
\text { is } 0.50-5.48 \mathrm{~m} \text {. }\end{array}$ & 0.19 & 6.22 & 0 & 6.22 & 0.54 & 1 & 6.95 & $\begin{array}{l}\text { Least } \\
\text { project } \\
\text { investmen } \\
\mathrm{t}\end{array}$ & $\begin{array}{l}\text { Large } \\
\text { demolitio } \\
\text { n volume }\end{array}$ \\
\hline $\begin{array}{l}\text { Co } \\
\text { mbi } \\
\text { nati } \\
\text { on } \\
\text { sch } \\
\text { em } \\
\text { e2 }\end{array}$ & $\begin{array}{l}\text { cascade } \\
\text { optimization } \\
\text { reconstruction } \\
+\quad \text { river } \\
\text { regulation }+ \\
\text { once-in-10- } \\
\text { years flood } \\
\text { dike } \\
\text { construction }+ \\
\text { tunnel flood } \\
\text { diversion }\end{array}$ & $\begin{array}{l}\text { The river channel regulation is } \\
5.79 \mathrm{~km} \text {; the levee construction } \\
\text { involves the demolition area of } \\
10 \text { million } \mathrm{m}^{2} \text {, and the flood } \\
\text { diversion tunnel involves the } \\
\text { expropriation area of } 101.13 \\
\text { million } \mathrm{m}^{2} \text {; the newly built } \\
\text { levee is } 4314 \mathrm{~m} \text { according to } \\
\text { the once-in-a-decade water } \\
\text { level, and the levee height is } \\
0.06-3.79 \mathrm{~m} \text {; three pressure- } \\
\text { free gate tunnels }(8 \mathrm{~m} \times 11.41 \\
\mathrm{m} \text { in width) of } 6.12 \mathrm{~km} \text { are } \\
\text { constructed, and the designed } \\
\text { flood diversion flow is } 800 \\
\mathrm{~m}^{3} / \mathrm{s} \text {. }\end{array}$ & 0.19 & 6.00 & 0.36 & 6.36 & 0.34 & 22.56 & $\begin{array}{c}29.4 \\
5\end{array}$ & $\begin{array}{l}\text { Small } \\
\text { scale of } \\
\text { flood } \\
\text { diversion } \\
\text { and less } \\
\text { investmen } \\
t\end{array}$ & $\begin{array}{l}\text { Large } \\
\text { demolitio } \\
\text { n volume }\end{array}$ \\
\hline $\begin{array}{l}\text { Co } \\
\text { mbi } \\
\text { nati } \\
\text { on } \\
\text { sch } \\
\text { em } \\
\text { e } 3\end{array}$ & $\begin{array}{l}\text { cascade } \\
\text { optimization } \\
\text { reconstruction } \\
+\quad \text { river } \\
\text { regulation }+ \\
\text { once in five } \\
\text { years dike } \\
\text { construction }+ \\
\text { tunnel flood } \\
\text { diversion }\end{array}$ & $\begin{array}{l}\text { The river channel regulation is } \\
5.79 \mathrm{~km} \text {; the levee construction } \\
\text { involves the demolition area of } \\
27.5 \text { million } \mathrm{m}^{2} \text {, and the flood } \\
\text { diversion tunnel involves the } \\
\text { expropriation area of } 109.4 \\
\text { million } \mathrm{m}^{2} \text {; the newly built } \\
\text { levee is } 2191 \mathrm{~m} \text { at the once-in- } \\
\text { five-year water level, and the } \\
\text { levee height is } 0.02-2.20 \mathrm{~m} \text {; } \\
\text { three parallel unconfined gate- } \\
\text { type tunnels ( } 11.5 \mathrm{~m} \text { in width } \\
\text { and } 15.32 \mathrm{~m} \text { in height) with } \\
6.12 \text { km in length are } \\
\text { constructed, and the designed } \\
\text { flood diversion flow is } 1630 \\
\mathrm{~m}^{3} / \mathrm{s} \text {. }\end{array}$ & 0.19 & 1.65 & 0.37 & 2.02 & 0.16 & 41.31 & $\begin{array}{c}43.6 \\
8\end{array}$ & $\begin{array}{l}\text { The levee } \\
\text { length and } \\
\text { height are } \\
\text { the } \\
\text { smallest, } \\
\text { and the } \\
\text { removal } \\
\text { amount is } \\
\text { less. }\end{array}$ & $\begin{array}{l}\text { Large } \\
\text { investme } \\
\text { nt in } \\
\text { projects }\end{array}$ \\
\hline $\begin{array}{l}\text { Co } \\
\text { mbi } \\
\text { nati } \\
\text { on } \\
\text { sch } \\
\text { em } \\
\text { e } 4\end{array}$ & $\begin{array}{l}\text { cascade } \\
\text { optimization } \\
\text { reconstruction } \\
+\quad \text { river } \\
\text { regulation }+ \\
\text { tunnel flood } \\
\text { diversion }\end{array}$ & $\begin{array}{l}\text { The river channel regulation is } \\
5.79 \mathrm{~km} \text {; the flood diversion } \\
\text { tunnel involves the requisition } \\
\text { area of } 114,500 \mathrm{~m}^{2} \text {; three } \\
\text { parallel unconfined city gate } \\
\text { tunnels ( } 13 \mathrm{~m} \text { wide and } 16.38 \\
\mathrm{~m} \text { high) with a length of } 6.12 \\
\mathrm{~km} \text { are constructed, and the } \\
\text { designed flood diversion flow } \\
\text { is } 1940 \mathrm{~m}^{3} / \mathrm{s} \text {. }\end{array}$ & 0.19 & / & 0.40 & 0.40 & / & 52.68 & $\begin{array}{c}53.2 \\
7\end{array}$ & $\begin{array}{l}\text { No } \\
\text { demolitio } \\
n\end{array}$ & $\begin{array}{l}\text { Difficulty } \\
\text { in } \\
\text { technolog } \\
\text { y and } \\
\text { large } \\
\text { investme } \\
\text { nt in } \\
\text { flood } \\
\text { diversion } \\
\text { tunnel }\end{array}$ \\
\hline
\end{tabular}

Note: The cascade optimization reconstruction is taken as the basic scheme in each combination scheme. When comparing the schemes, the cascade optimization reconstruction cost is not included in the investment cost. 
regulation + once-in-five-year flood requirement dike + tunnel flood diversion) and combination scheme 4 (cascade optimization reconstruction + river regulation + tunnel flood diversion) are $1630 \mathrm{~m}^{3} / \mathrm{s}$ and $1940 \mathrm{~m}^{3} / \mathrm{s}$ respectively. Three parallel unconfined gate-type tunnels are adopted, and the maximum cross-section sizes of single tunnel are $11.50 \mathrm{~m} \times 15.32 \mathrm{~m}$ and $13 \mathrm{~m} \times 16.38 \mathrm{~m}$ respectively. It is difficult to construct this engineering by referring to similar engineering experience. The second combination scheme (cascade optimization reconstruction + river regulation + once-in-10-year dike + tunnel flood diversion) has moderate flood diversion scale $\left(800 \mathrm{~m}^{3} / \mathrm{s}\right)$ and maximum height of dike $(3.79 \mathrm{~m})$, with less technical difficulty. The first combination scheme (cascade optimization reconstruction + river regulation + once in 20 years embankment) is mainly composed of assembled retaining wall, embankment combination, flood control wall and wave-proof wall. The maximum height of embankment is $5.15 \mathrm{~m}, 4.77 \mathrm{~m}$, $3.61 \mathrm{~m}$ and $1.11 \mathrm{~m}$, respectively. According to the topographic and geological conditions of the main urban area of Qijiang District, the technical difficulty is the smallest. Therefore, from the point of view of technical difficulty, combination scheme one and combination scheme two are better.

\section{(3) Land expropriation and immigration}

The construction of embankment mainly involves land requisition and demolition of residential buildings, and the flood diversion tunnel mainly involves land requisition and demolition of cultivated garden land, forest land and other land. Therefore, the implementation of the demolition area of flood diversion tunnel is less difficult than that of the demolition area in embankment. Combination scheme 1 does not include flood diversion tunnel scheme, combination scheme 2, combination scheme 3 and combination scheme 4 have little difference in the area of demolition area involved in the construction of the tunnel. The area of land requisition and demolition involved in the first and second combination schemes is larger, which are $103,600 \mathrm{~m}^{2}$ and $10,000 \mathrm{~m}^{2}$ respectively. The third combination scheme involves only $27,500 \mathrm{~m}^{2}$ of land requisition and demolition, and the fourth combination scheme does not include the scheme of embankment construction. Comparing comprehensively, the combination scheme 4 is better, and the combination scheme 3 is slightly better among the other three.

\section{(4) Project investment.}

After preliminary calculation, the total investment in river regulation and tunnel flood diversion projects of combination scheme 1 (cascade optimization reconstruction + river regulation + once- in-20-years requirement dike), combination scheme 2 (cascade optimization reconstruction + river regulation + once- in10 -years requirement dike + tunnel flood diversion), combination scheme 3 (cascade optimization reconstruction + river regulation + once- in-5-years requirement dike + tunnel flood diversion) and combination scheme 4 (cascade optimization reconstruction) is 695 million yuan, 2.945 billion yuan,
4.368 billion yuan and 5.327 billion yuan, respectively. Scheme three and four have larger investment, scheme two is the second, and scheme one is the most economical.

\section{(5) Project investment}

After preliminary calculation, the total investment in river regulation and tunnel flood diversion projects of combination scheme 1 (cascade optimization reconstruction + river regulation + once- in-20-years requirement dike), combination scheme 2 (cascade optimization reconstruction + river regulation + once- in10-years requirement dike + tunnel flood diversion), combination scheme 3 (cascade optimization reconstruction + river regulation + once- in-5-years requirement dike + tunnel flood diversion) and combination scheme 4 (cascade optimization reconstruction) is 695 million yuan, 2.945 billion yuan, 4.368 billion yuan and 5.327 billion yuan, respectively. Scheme three and four have larger investment, scheme two is the second, and scheme one is the most economical.

The diversion tunnel can be used for both flood diversion in flood season and transportation in non-flood season. According to preliminary calculation, the construction of 4-lane national highway with double tunnels is $612 \mathrm{~km}$, with an investment of about 1.53 billion yuan. That is to say, the construction of $800 \mathrm{~m}^{3} / \mathrm{s}$ flood diversion tunnel in combination scheme 2 only increases by 762 million yuan compared with highway investment, that is, the total investment in combination scheme 2 (excluding the share of highway) is about 1.415 billion yuan, which is more than 720 million yuan than that of combination scheme 1 .

\section{(6) Impact on urban landscape}

The combination scheme 3 (cascade optimization reconstruction + river regulation + once-in-5-years requirement dike + tunnel flood diversion) is closer to the river bank, and the maximum height of the dike is $2.20 \mathrm{~m}$. Combination scheme 4 (cascade optimization reconstruction + river regulation + tunnel flood diversion) does not build dikes to maintain the current situation of urban reaches. The embankment lines of combination scheme 1 (cascade optimization reconstruction + river regulation +20 years once dike) and combination scheme 2 (cascade optimization reconstruction + river regulation +10 years once dike + tunnel flood diversion) are identical, and the maximum height of dike body is $5.48 \mathrm{~m}$ and $3.79 \mathrm{~m}$, respectively. Although the height of dike is relatively high, it can be avoided or reduced by optimization of dike line and dike type for its adverse impact on the urban landscape, and even more strengthen the hydrophilicity of the city. Specific manifestations are as follows: first, after planning the demolition of buildings outside the embankment line, we should build a waterfront landscape belt of "landscapepastoral-city" integration, construct green open space, provide more leisure and recreation places for citizens, and create a friendly and pleasant ecological environment; second, the left bank of the Qijiang River from Rainbow Bridge to Liujiatuo Crossing and the right 
bank from Tuowan Bridge to Tonghui Estuary is relatively low-lying, so the assembled flood control wall is planned to use, because it is easy to store, and simple and beautiful in appearance. The assembled flood control wall can withstand floods in flood season, and is disassembled and stored in warehouses in non-flood season, so it meets the requirements of urban flood control and environmental landscape, and reduces the amount of land expropriation and demolition. The existing levees as both flood control and leisure corridors in the left bank section from Railway Station Ferry to Chuanjiang Mao Line sales department, and the section from Tuowan Bridge and Tuowan Banshan Apartment are maken full use, adopting 0.19-1.11 and $0.5 \mathrm{~m}$ waveproof walls respectively, and backfilling measures in some low-lying sections; Fourth, the combination of embankment and road is adopted in the Sinopec Railway Station Ferry Section and Liujiatun Ferry Dachang junction section on the left bank of Qijiang River and railway station-Tuowan bridge section on the right bank of Qijiang River, which raises the elevation of highway pavement and uses 1:2.5 grass planting slope to shape the landscape belt. Generally speaking, combination scheme 1 and combination scheme 2 are more in line with the future development direction of the main urban area of Qijiang District.

\section{(7) Benefit of flood diversion tunnel}

At present, more highways have been built and planned to cross the city, which has brought tremendous traffic pressure to the urban area. Among them, National Highway 210 crosses the urban area, which not only disturbs the city greatly, but also restricts its own transport capacity. About $3.21 \mathrm{~km}$ of National Highway 210 crosses the urban area is below the flood level of once in 20 years. When the flood occurs once in 20 years, the traffic will be interrupted, which needs further optimization. According to the Urban-Rural Master Plan of Qijiang District, Chongqing (2012-2020), it is planned that the section of National Highway 210 passing through Qijiang City will be moved out to the edge of the urban area to reduce the interference of transit traffic to the urban area. At the same time, the grade of the section will be upgraded to one level, and it will be combined with the urban expressway on the eastern side of the urban area to form an expressway ring along the periphery of the urban area. The planned flood diversion tunnel can be used as both flood diversion in flood season and transportation in non-flood season and it is mainly used as highway. It can be considered as the "second passage" of National Highway 210. When the forecasted inflow exceeds the safe discharge of the main urban rivers in Qijiang District, the flood diversion will be used. The comprehensive benefit is obvious.

\section{(8) Recommendation scheme}

In terms of flood control effect, the four combination schemes are the same; in terms of engineering technical difficulty, combination scheme one and combination scheme two are better, while the other two schemes are more difficult because of the large scale of flood diversion; in terms of land expropriation and immigration, combination scheme four and combination scheme three are better; in terms of the impact on urban landscape, combination scheme 1 and combination scheme 2 are more in line with the requirements of urban general planning; in terms of Engineering investment, combination scheme 1 is the best, followed by combination scheme 2; from the comprehensive benefit point of view, combination scheme 1 takes into account both urban flood control and landscape needs, combination scheme 2 is conducive to reducing traffic pressure in the main urban area, the engineering benefit of the above two schemes is obvious.

The development orientation of the main urban area of Qijiang District should give priority to ensuring the safety of people's lives and property, and take into account the requirements of flood control, environmental renovation, urban construction and development as a whole. After comprehensive comparison, this flood control plan recommends the adoption of combination scheme 1, that is, dismantling the three cascades of Shixikou, Dachang and Chetan, and adopting the scheme that remoulds 5 cascades of Yangtidong, Zhutan, Qiaohe, Qiaoxikou and Wufu, dredges $5.79 \mathrm{~km}$ from Rainbow Bridge to North Bridge (excluding the site of Qijiang Bridge) and Beidouchang to Qingxi River Estuary, demolishes about $103,000 \mathrm{~m}^{2}$ of all houses outside the embankment, and builds a new embankment with the length of $4978 \mathrm{~m}$ at once-in-20-year flood water level. In addition, if the Qijiang River wants to implement the diversion of National Highway 210, it can also consider the scheme of combining with flood diversion tunnel, that is, adopting the combination scheme 2 (cascade optimization reconstruction + river regulation + once-in10- years requirement dike + tunnel flood diversion).

After the implementation of the recommended scheme (combination scheme 1), the flood control standard of the main urban area of Qijiang District will meet the requirement of once-in-20-years flood. Considering the inflow of tributaries such as Tonghui River and Shaxi River, the discharge capacity of Qijiang Railway Station to Tonghui River Estuary, Tonghui River Estuary to Shaxi River Estuary, Shaxi River Estuary to North Bridge will reach $4841 \mathrm{~m}^{3} / \mathrm{s}, 4900 \mathrm{~m}^{3} / \mathrm{s}$ and $4920 \mathrm{~m}^{3} / \mathrm{s}$ respectively.

\section{Conclusion}

As the Qijiang River is a mountainous river, the time of upstream flood spreading to the main urban area of Qijiang District is relatively short, and there are many bends in the middle and lower reaches of the main river, and the river gradient is gentle, but the flood discharge is not smooth. In addition, nine navigation cascades and many bridges built in the middle and lower reaches of the river block the flood, and the construction of dykes is not up to the standard, and the construction of towns occupies the river course. For these reasons, the current flood control capacity of the main urban area of Qijiang District is less than the requirement of once-in-five-years flood, with frequent floods, and the situation of flood control is not optimistic. The plan raises the flood 
control standard of the main urban area of Qijiang District to the requirement of once-in-20-years flood through comprehensive measures such as building new embankments reasonably, dredging the waterway, optimizing and rebuilding shipping cascades, etc. The three cascades of Dachang, Chetan and Shixikou are planned to be dismantled, and the five cascades of Wufu, Qiaoxikou, Qiaohe, Zhutan and Yangtidong are optimized and rebuilt by the whole sluice scheme; the river dredging regulation length is $5.79 \mathrm{~km}$; the dike with a length of $4.98 \mathrm{~km}$ is built at a flood level in 20 years after the implementation of the sluice dam optimization and river channel regulation scheme, and the houses outside the dike are demolished and relocated 103,000 $\mathrm{m}^{2}$. After the implementation of the scheme, the flood control capacity of the main urban area of Qijiang District can reach the requirement of once-in-20-years flood.

On the basis of the implementation of flood control engineering measures, it is suggested to improve the non-engineering measures such as flood control command system and flood control plan, to implement the " river chief system" under the responsibility of the executive head of the government, and to realize the fine management of river courses and flood control projects.

\section{Acknowledgements}

The authors gratefully acknowledge the support of the National Key Research and Development Program of China (Grant Nos. 2017YFC0405305, Grant Nos. 2018YFC1508005).

\section{References}

1. Sichuan Provincial Meteorological Bureau Reference Room, Recent 500 years of drought and flood history in Sichuan Province (Chengdu 1978)

2. Chongqing Water Conservancy and Electric Power Building Survey and Design Institute, Chongqing Bayu Water Conservancy Planning Institute, Flood risk map compilation of Qijiang River in Chongqing (Chongqing 2015)

3. Chongqing Heyuan Flood Control Technical Service Center, Flood analysis and calculation of the river channel "Five-Line" in Chongqing's Qijiang District (Chongqing 2014)

4. Ministry of Water Resource P.R. China, Standard for flood control (GB 50201-2014) (China Planning Press, Beijing 2015)

5. Chongqing Water Conservancy Planning Institute, Qijiang County flood control planning (Chongqing 2007)

6. Qijiang County Flood Control Planning Office, Flood control planning of Qijiang River basin (2000-2020) (Qijiang 1999)

7. Chongqing Traffic Planning Survey and Design Institute, Qijiang shipping comprehensive development plan (Chongqing 2016)

8. Chongqing Productivity Development Center, Chongqing Xike Water Transport Engineering Consulting Center, Research on comprehensive development plan of Qijiang shipping (Chongqing 2015) 